\title{
Life cycle of Neocalanus flemingeri (Crustacea: Copepoda) in the Oyashio region, western subarctic Pacific, with notes on its regional variations
}

\author{
Toru Kobari* ${ }^{*}$ Tsutomu Ikeda \\ Biological Oceanography, Faculty of Fisheries, Hokkaido University, 3-1-1 Minato-machi, Hakodate, \\ Hokkaido 041-0821, Japan
}

\begin{abstract}
The life cycle of Neocalanus flemingeri was investigated by analyzing population structure data collected monthly at Site H in the Oyashio region, Japan, from September 1996 through October 1997. Additional non-time-series sampling was also done at several stations covering the entire subarctic Pacific, Japan Sea and Okhotsk Sea, as a basis for regional comparison of the differing life cycles and body sizes of this species. At Site H, N. flemingeri spawned between January and February below $250 \mathrm{~m}$ depth. Copepodite Stage 1 (C1) occurred in March, and most of these had developed into C5 by early June, i.e. by the end of the phytoplankton bloom. A portion of the C4 population ceased development and remained at the thermocline to $500 \mathrm{~m}$ layer throughout the year. The remainder developed to C5, then migrated to 250-2000 m depth in June, and matured immediately. C6 males were present in May to July and died immediately thereafter. C6 females were observed in June to December with immature gonads and in January to February with fully mature gonads. The life cycle of $N$. flemingeri was estimated as annual for most of the population, but the small population overwintering as $\mathrm{C} 4$ may have a biennial life cycle. While the prosome length distributions of the C2, C3, C6 males and C6 females were unimodal, C4 and C5 exhibited bimodality. We believe this bimodality reflects sexual dimorphism for C4 and C5. Possible development sequences of each of the 2 size groups are proposed in relation to annual and biennial life cycles of $N$. flemingeri. Temporal population-structure data in other regions suggested an annual life cycle for the populations in the central-eastern subarctic Pacific, and a possible mixture of various degrees of annual/biennial life cycles for the populations in the western subarctic Pacific, Japan Sea and Okhotsk Sea. Geographical comparison of the prosome length of the C6 females between the Oyashio (Site H) and other regions indicated significantly larger specimens in the Okhotsk Sea, with smaller individuals in the eastern and part of the western subarctic Pacific. Possible causes for regionl variability in life cycle and body size are discussed.
\end{abstract}

KEY WORDS: Neocalanus flemingeri $\cdot$ Life cycle $\cdot$ Ontogenetic vertical migration $\cdot$ Body size $\cdot$ Sexual dimorphism · Western North Pacific

\section{INTRODUCTION}

The subarctic Pacific Ocean and adjacent Bering, Japan and Okhotsk Seas have common sets of pelagic species (cf. Zenkevitch 1963). Among the zooplankton,

\footnotetext{
*Present address: Miyagi Prefecture Fisheries Research and Development Center, 97-6 Sodenohama, Watanoha, Ishinomaki Miyagi 986-2135, Japan. E-mail: toru.k@f3dion.ne.jp
}

copepods are an integral component. Large grazers such as Neocalanus cristatus, N. plumchrus and Eucalanus bungii often account for 80 to $90 \%$ of the zooplankton biomass of the surface layer (Vinogradov 1970). These large grazing copepods are known to be preyed upon by various pelagic fishes, whales and sea birds (Nemoto 1963, Fukataki 1967,1969, Taka et al. 1982, Odate 1994, Hunt et al. 1998), and are therefore a vital link between primary production and predators in these regions. 
Neocalanus flemingeri was only recently described as a new species by Miller (1988). Before Miller's description, this species had long been confused with $N$. plumchrus because of their similar morphology. Studies have shown that $N$. flemingeri and N. plumchrus have dissimilar life cycles (Miller \& Clemons 1988, Miller \& Terazaki 1989, Tsuda et al. 1999). Ontogenetic vertical migration and the life cycle of $N$. flemingeri were first evaluated at Stn $\mathrm{P}$ in the eastern subarctic Pacific (Miller \& Clemons 1988), and then in the Japan Sea (Miller \& Terazaki 1989). According to these studies, the life cycle of $N$. flemingeri is annual in the eastern subarctic Pacific, but biennial in the Japan Sea. Recently, Tsuda et al. (1999) studied the life cycle of $N$. flemingeri in the Oyashio region, Japan, and noted the occurrence of 2 distinct size groups in Copepodite Stages 4 and 5 (C4 and C5). They interpreted the smaller size group to be the local population in the Oyashio region and the larger size group to be individuals transported from the Okhotsk Sea. From the viewpoint of ontogenetic vertical migration of $N$. flemingeri (near the surface to $>1000 \mathrm{~m}$ depth: Miller \& Clemons 1988, this study), however, the sampling by Tsuda et al. (1999) did not cover the entire depth range of $N$. flemingeri. Clearly, a more thorough collection covering its entire habitat is needed to gain a better picture of the life cycle pattern of $N$. flemingeri in the Oyashio region.

In this study, we propose an alternative life cycle of $\mathrm{Neo}$ calanus flemingeri to that hypothesized by Tsuda et al. (1999); our study is based on new year-round population data collected from the surface to $\leq 2000 \mathrm{~m}$ depth, and develops an alternative interpretation (sexual dimorphism) for the 2 size groups seen in the late copepodite stages. Regional variations in the life cycle and body size of $N$. flemingeri in the subarctic Pacific and its marginal seas are also discussed.

Fig. 1. (a) Current systems (redrawn from Favorite et al. 1976) and (b) sampling stations in the subarctic Pacific

Ocean and its neighboring waters

\section{METHODS}

Monthly depth-stratified sampling was done in the Oyashio region $\left(41^{\circ} 30^{\prime}\right.$ to $42^{\circ} 30^{\prime} \mathrm{N}$ latitude, $145^{\circ} 00^{\prime}$ to $146^{\circ} 00^{\prime} \mathrm{E}$ longitude) off southeastern Hokkaido (referred to hereafter as Site $\mathrm{H}$ ). We also obtained occasional samples from 3 additional stations in the western, 1 station in the central, and 2 stations in the eastern subarctic Pacific, 4 stations in the Japan Sea, 2 stations in the Okhotsk Sea and 1 station in the western Bering Sea (Fig. 1, Table 1). Except for the sampling in the Bering Sea (February 1993), all other samples were collected from September 1996 to October 1997.

Zooplankton were collected with a closing net $(60 \mathrm{~cm}$ mouth diam., $100 \mu \mathrm{m}$ mesh size; Kawamura 1968, 1989), equipped with a Rigosha flow-meter in its mouth ring and a TSK depth-distance recorder or RMD depth meter on its suspension cable. The net was towed vertically at a speed of $1 \mathrm{~m} \mathrm{~s}^{-1}$, usually through 5 discrete strata: 0 (surface) to the bottom of the thermocline, the bottom of thermocline to 250,250 to $500 \mathrm{~m}, 500$ to $1000 \mathrm{~m}$, and 1000 to $\leq 2000 \mathrm{~m}$ (Table 1). When the sampling failed to obtain a complete discrete depth series
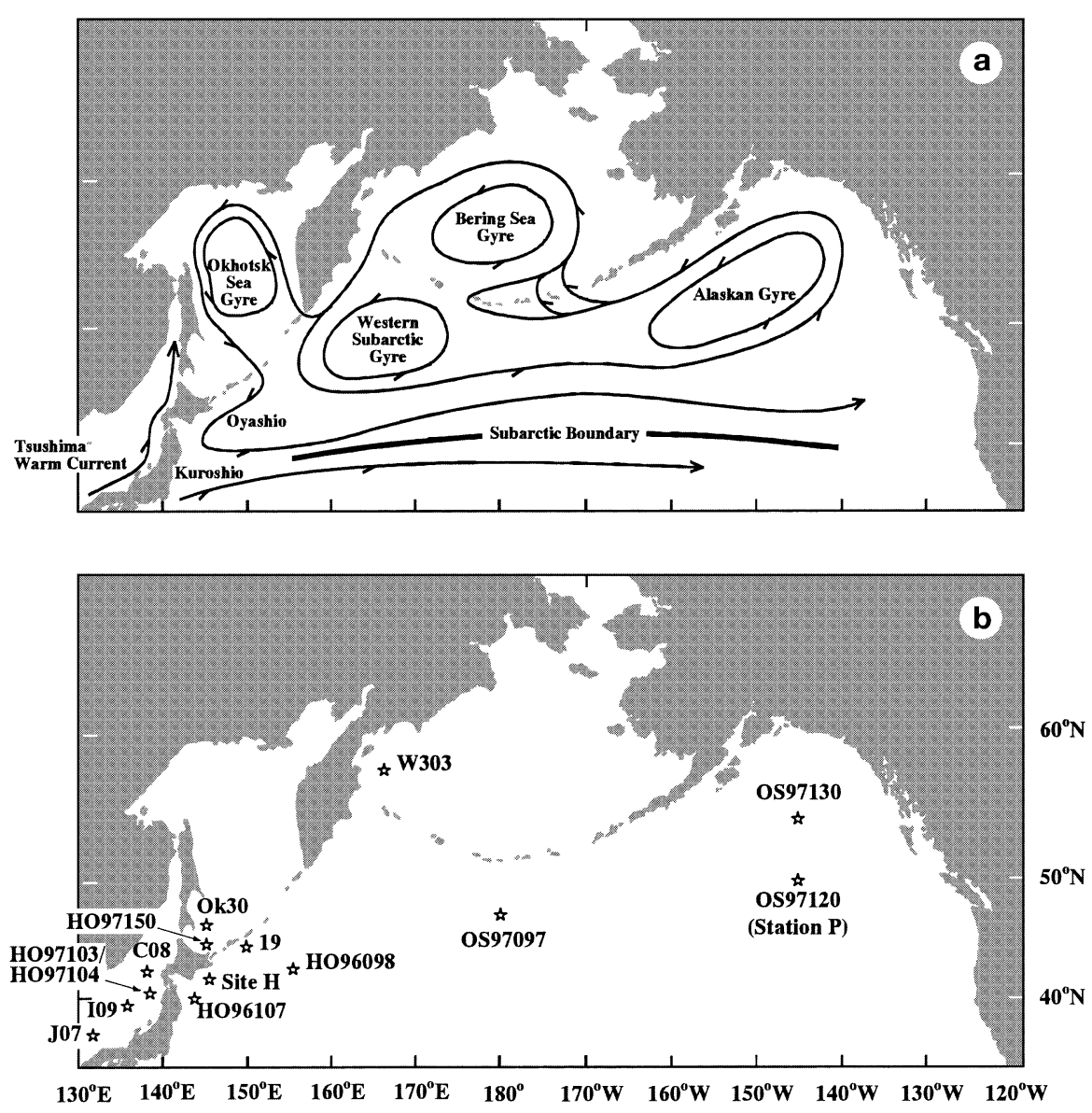
during the monthly samplings, missing depth-stratum data were time-interpolated from data for the previous and subsequent sampling dates. Since the samples were obtained without standardizing the time of day, diel vertical migration of Neocalanus flemingeri could be a potential source of error in estimating the vertical distribution pattern of $N$. flemingeri. However, N. flemingeri is known to carry out little or no diel vertical migration (Mackas et al. 1993, Tsuda \& Sugisaki 1994, Kobari \& Ikeda unpubl. data). For the isolated samples in the Bering Sea, where specimens were used for prosome length measurements only, a WP-2 net $(57 \mathrm{~cm}$ mouth diam., $200 \mu \mathrm{m}$ mesh size; UNESCO 1968) was used. After collection, zooplankton samples were preserved in $5 \%$ formalin-seawater buffered with borax.
Temperature and salinity profiles were determined with a CTD system at each sampling of zooplankton. Chlorophyll a concentration data at Site H were supplied by $H$. Kasai of Hokkaido National Fisheries Research Institute.

In the laboratory, Neocalanus flemingeri was sorted from the zooplankton samples, then separated into 5 copepodite stages (C2 to $\mathrm{C} 6$ ) under a dissecting microscope. The C1 of $N$. flemingeri could not be distinguished from that of $N$. plumchrus because of undeveloped second maxilla and the mandibular gnathobase. C6 specimens were separated into males and females. N. flemingeri was distinguished from N. plumchrus by its smaller proportion of second maxilla to prosome (Tsuda et al. 1999), its wider tooth row on the

Table 1. Zooplankton sampling data in the subarctic Northwest (NW), Northcentral (NC) and Northeast (NE) Pacific and its neighboring waters. NT: nighttime; DT: daytime; Os: TS 'Oshoro Maru'; Ho: TS 'Hokusei Maru'; Hs: RV 'Hokushin Maru'; Hk: RV ‘Hokko Maru'; Ts: RV ‘Tansei Maru'; Ky: RV 'Kaiyo Maru'; WP-2: WP-2 net; G: closing type net

\begin{tabular}{|c|c|c|c|c|c|c|}
\hline $\begin{array}{l}\text { Area } \\
\text { Station code }\end{array}$ & Position & $\begin{array}{l}\text { Sampling } \\
\text { date }\end{array}$ & Time & Ship & Net & Discrete sampling depth (m) \\
\hline \multicolumn{7}{|l|}{ NW Pacific } \\
\hline \multirow[t]{15}{*}{ Site H } & $42^{\circ} 00^{\prime} \mathrm{N}, 145^{\circ} 00^{\prime} \mathrm{E}$ & 4 Sep 1996 & NT & Os & G & $0-30,30-250,250-500,500-1000,1000-1800$ \\
\hline & $41^{\circ} 30^{\prime} \mathrm{N}, 145^{\circ} 47^{\prime} \mathrm{E}$ & 19 Sep 1996 & NT & Ho & G & $0-30,30-250,250-500,500-1000,1000-1500$ \\
\hline & $41^{\circ} 30^{\prime} \mathrm{N}, 145^{\circ} 47^{\prime} \mathrm{E}$ & 2 Oct 1996 & DT & Ho & G & $0-30,30-250,250-500,500-1000,1000-1500$ \\
\hline & $41^{\circ} 30^{\prime} \mathrm{N}, 146^{\circ} 00^{\prime} \mathrm{E}$ & 8 Dec 1996 & NT & Hs & G & $0-80,80-250,250-500,500-1000,1000-1700$ \\
\hline & $42^{\circ} 30^{\prime} \mathrm{N}, 145^{\circ} 00^{\prime} \mathrm{E}$ & 13 Jan 1997 & DT & $\mathrm{Hk}$ & $\mathrm{G}$ & $0-50,10-500,300-1700$ \\
\hline & $41^{\circ} 30^{\prime} \mathrm{N}, 146^{\circ} 00^{\prime} \mathrm{E}$ & 20 Feb 1997 & NT & Hs & $\mathrm{G}$ & $0-100,100-250,250-500$ \\
\hline & $41^{\circ} 45^{\prime} \mathrm{N}, 145^{\circ} 22^{\prime} \mathrm{E}$ & 17 Mar 1997 & NT & $\mathrm{Hk}$ & $\mathrm{G}$ & $0-100,100-250,250-500,500-1000,1000-2000$ \\
\hline & $41^{\circ} 30^{\prime} \mathrm{N}, 145^{\circ} 47^{\prime} \mathrm{E}$ & 11 Apr 1997 & NT & Ho & $\mathrm{G}$ & $0-150,150-250,250-500,500-1000,1000-1500$ \\
\hline & $42^{\circ} 01^{\prime} \mathrm{N}, 145^{\circ} 21^{\prime} \mathrm{E}$ & 7 May 1997 & NT & $\mathrm{Hk}$ & G & $0-150,500-1000,1000-2000$ \\
\hline & $41^{\circ} 30^{\prime} \mathrm{N}, 145^{\circ} 47^{\prime} \mathrm{E}$ & 4 Jun 1997 & NT & Os & G & $0-80,80-250,250-500,500-1000$ \\
\hline & $41^{\circ} 30^{\prime} \mathrm{N}, 145^{\circ} 47^{\prime} \mathrm{E}$ & 23 Jun 1997 & NT & Но & G & $0-20,20-250,250-500,500-1000$ \\
\hline & $41^{\circ} 30^{\prime} \mathrm{N}, 145^{\circ} 47^{\prime} \mathrm{E}$ & 2 Jul 1997 & NT & Ho & G & $0-40,40-250,250-500,500-1000,1000-2000$ \\
\hline & $41^{\circ} 30^{\prime} \mathrm{N}, 145^{\circ} 47^{\prime} \mathrm{E}$ & 17 Aug 1997 & NT & Os & G & $0-80,80-250,250-500,500-1000,1000-2000$ \\
\hline & $41^{\circ} 29^{\prime} \mathrm{N}, 145^{\circ} 47^{\prime} \mathrm{E}$ & 26 Aug 1997 & DT & Ts & G & $0-20,20-250,250-500,500-1000,1000-2000$ \\
\hline & $41^{\circ} 30^{\prime} \mathrm{N}, 145^{\circ} 47^{\prime} \mathrm{E}$ & 5 Oct 1997 & NT & Ho & G & $0-75,75-250,250-500,500-1000,1000-2000$ \\
\hline HO96098 & $42^{\circ} 30^{\prime} \mathrm{N}, 155^{\circ} 00^{\prime} \mathrm{E}$ & 27 Sep 1996 & NT & Ho & G & $0-40,40-250,250-500,500-1000,1000-1500$ \\
\hline HO96107 & $40^{\circ} 32^{\prime} \mathrm{N}, 144^{\circ} 29^{\prime} \mathrm{E}$ & 3 Oct 1996 & DT & Ho & $\mathrm{G}$ & $0-30,30-250,250-500,500-1000,1000-1500$ \\
\hline 19 & $44^{\circ} 26^{\prime} \mathrm{N}, 149^{\circ} 40^{\prime} \mathrm{E}$ & 16 Oct 1996 & DT & Ky & G & $0-50,50-250,250-500,500-1000,1000-2000$ \\
\hline \multicolumn{7}{|l|}{ NC Pacific } \\
\hline OS97097 & $47^{\circ} 00^{\prime} \mathrm{N}, 180^{\circ} 00^{\prime} \mathrm{E}$ & 18 Jun 1997 & NT & Os & G & $0-100,100-250,250-500,500-1000,1000-2000$ \\
\hline \multicolumn{7}{|c|}{ NE Pacific } \\
\hline OS97120 (= Stn P) & $50^{\circ} 00^{\prime} \mathrm{N}, 145^{\circ} 00^{\prime} \mathrm{W}$ & 5 Jul 1997 & NT & Os & $\mathrm{G}$ & $0-40,40-250,250-500,500-1000,1000-2000$ \\
\hline OS97130 & $55^{\circ} 00^{\prime} \mathrm{N}, 145^{\circ} 00^{\prime} \mathrm{W}$ & 10 Jul 1997 & NT & Os & G & $0-40,40-250,250-500,500-1000,1000-2000$ \\
\hline \multicolumn{7}{|l|}{ Bering Sea } \\
\hline W303 & $57^{\circ} 08^{\prime} \mathrm{N}, 165^{\circ} 53^{\prime} \mathrm{E}$ & 8 Feb 1993 & NT & Ky & WP-2 & $0-500$ \\
\hline \multicolumn{7}{|l|}{ Japan Sea } \\
\hline $\mathrm{C} 08$ & $42^{\circ} 30^{\prime} \mathrm{N}, 137^{\circ} 30^{\prime} \mathrm{E}$ & 11 Jan 1997 & NT & Ky & $\mathrm{G}$ & $0-100,100-500,500-1000,1000-2000,2000-3000$ \\
\hline I09 & $39^{\circ} 00^{\prime} \mathrm{N}, 135^{\circ} 00^{\prime} \mathrm{E}$ & 24 Jan 1997 & NT & Ky & G & $0-100,100-500,500-1000$ \\
\hline J07 & $37^{\circ} 00^{\prime} \mathrm{N}, 131^{\circ} 30^{\prime} \mathrm{E}$ & 26 Jan 1997 & NT & Ky & G & $0-200,200-500,500-1000,1000-2000$ \\
\hline HO97103 & $40^{\circ} 48^{\prime} \mathrm{N}, 138^{\circ} 19^{\prime} \mathrm{E}$ & 19 Sep 1997 & DT & Ho & G & $0-100,100-250,250-500,500-1000,1000-2000$ \\
\hline HO97104 & $40^{\circ} 48^{\prime} \mathrm{N}, 138^{\circ} 19^{\prime} \mathrm{E}$ & 19 Sep 1997 & NT & Ho & G & $0-100,100-250,250-500,500-1000,1000-2000$ \\
\hline \multicolumn{7}{|l|}{ Okhotsk Sea } \\
\hline Ok30 & $46^{\circ} 00^{\prime} \mathrm{N}, 145^{\circ} 00^{\prime} \mathrm{E}$ & 9 Nov 1996 & DT & Ky & $\mathrm{G}$ & $0-50,50-250,250-500,500-1000,1000-2000$ \\
\hline HO97150 & $44^{\circ} 40^{\prime} \mathrm{N}, 145^{\circ} 20^{\prime} \mathrm{E}$ & 1 Oct 1997 & NT & Ho & $\mathrm{G}$ & $0-50,50-250,250-500,500-1000,1000-2000$ \\
\hline
\end{tabular}


mandibular gnathobase for $\mathrm{C} 2$ to $\mathrm{C} 5$, its smaller head/ prosome ratio for the $\mathrm{C} 6$ male, and its smaller width of the first urosome segment for the C6 female (Miller 1988). The sexual maturity of the C6 females was classified into the following 4 categories, based on gonad condition: dormant, developing, actively spawning and spent, following the criteria of Miller \& Clemons (1988). As an index of body size, the prosome length of specimens was measured under a dissecting microscope to the nearest $0.05 \mathrm{~mm}$.
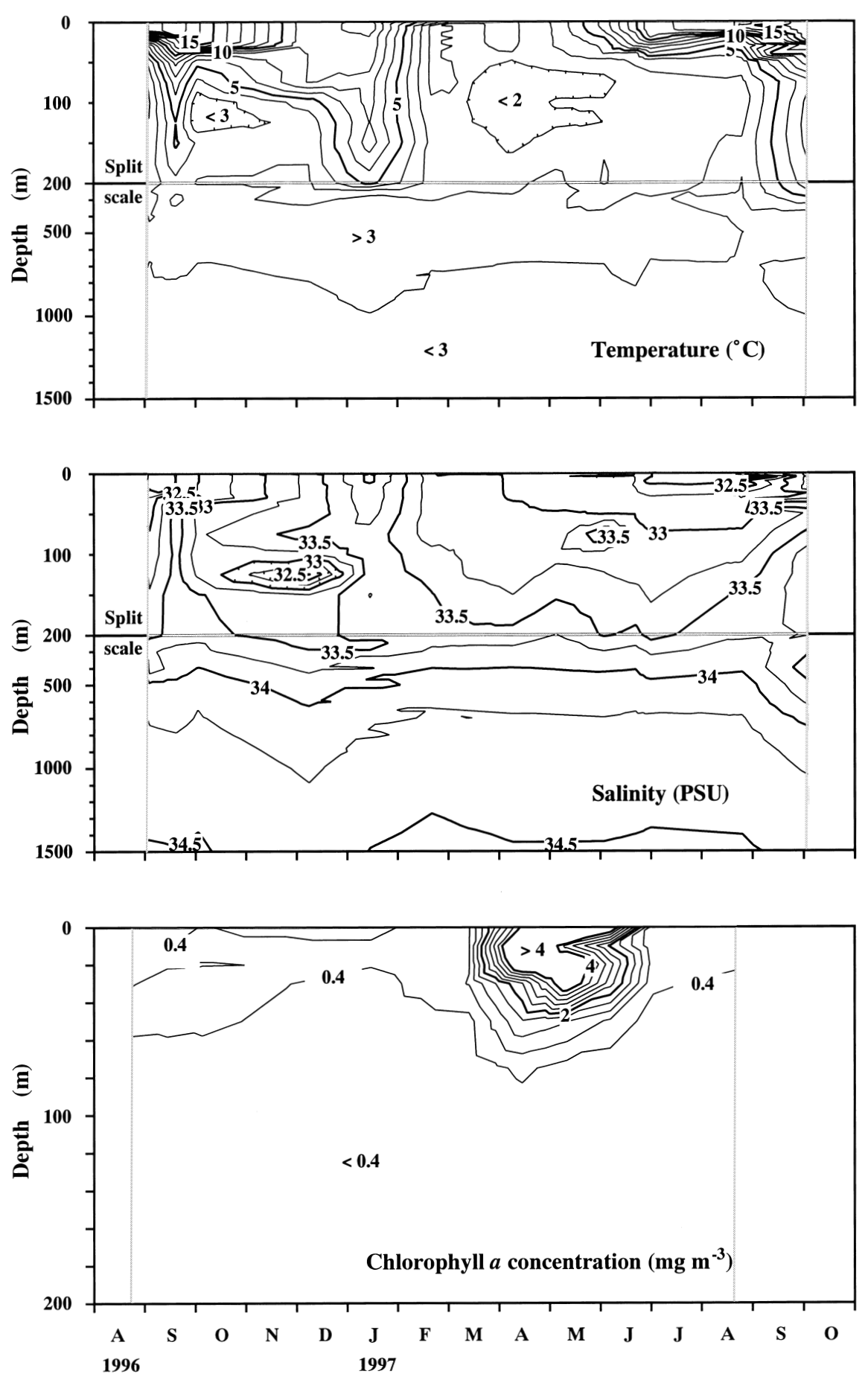

Fig. 2. Seasonal changes in vertical structures of temperature, salinity and chlorophyll a concentration at Site H from August 1996 to October 1997. Note that depth scale in the bottom panel is not the same as in the top 2 panels

\section{RESULTS}

\section{Hydrography}

Site H

The western boundary current of the subarctic circulation in the North Pacific is called the 'Oyashio'. It flows southwestward along the Kuril Islands and reaches the east coast of northern Honshu, Japan, then turns east at about $40^{\circ} \mathrm{N}$ (cf. Reid 1973). During its journey, the properties of Oyashio water are modified as a result of exchange with Okhotsk Sea water, Tsugaru Warm-Current water, and Kuroshio water (Kono 1996). Because of its meandering flow pattern, isolated loops of the Kuroshio extension are often entrapped between the downstream and return flows of the Oyashio and are called 'warm-core rings'.

Site $\mathrm{H}$ of this study is near the southern end of the alongshore flow of the Oyashio. Over the study period, surface temperatures ranged from $2{ }^{\circ} \mathrm{C}$ (March to April 1997) to $18^{\circ} \mathrm{C}$ (September to October 1996 and 1997) (Fig. 2). Oyashio water, characterized by salinities from 33.0 to $33.3 \mathrm{psu}$ and temperatures below $3^{\circ} \mathrm{C}$ (Ohtani 1971), occurred in the upper $150 \mathrm{~m}$ from February to April 1997. After April, less saline, seasonally warmed water (possibly originating from the Okhotsk Sea; T. Kono pers. comm.) occupied the upper $50 \mathrm{~m}$. Surface temperatures above $10^{\circ} \mathrm{C}$ were observed in September to November 1996 and in June to October 1997, when the thermocline was well established at 20 to $50 \mathrm{~m}$ in the water column. Effects of warmcore rings originating from the Kuroshio extension were seen in September of both 1996 and 1997, and from December 1996 to January 1997, as judged by temperature at $200 \mathrm{~m}$ $\left(>4^{\circ} \mathrm{C}\right)$ and salinity in the 0 to $200 \mathrm{~m}$ layer (>33.5 psu). The temperature and 
salinity in the 200 to $1500 \mathrm{~m}$ layer were stable and nearly constant at 2 to $3^{\circ} \mathrm{C}$ and 33.5 to $34.5 \mathrm{psu}$, respectively, throughout the year.

Phytoplankton biomass estimated from chlorophyll a (chl a) content showed a marked seasonality (Fig. 2). $\mathrm{Chl} a$ at the surface was around $0.4 \mathrm{mg} \mathrm{m}^{-3}$ from August 1996 to the end of February 1997, and then increased rapidly to $>9 \mathrm{mg} \mathrm{m}^{-3}$ in May 1997. During this period, concentrations above $2 \mathrm{mg} \mathrm{m}^{-3}$ extended down to $50 \mathrm{~m}$. The surface chl a concentrations had decreased to $2 \mathrm{mg} \mathrm{m}^{-3}$ by the end of June and to $0.4 \mathrm{mg} \mathrm{m}^{-3}$ toward the end of 1997. Chl a was consistently as low as $<0.4 \mathrm{mg} \mathrm{m}^{-3}$ below $100 \mathrm{~m}$ depth throughout the year.

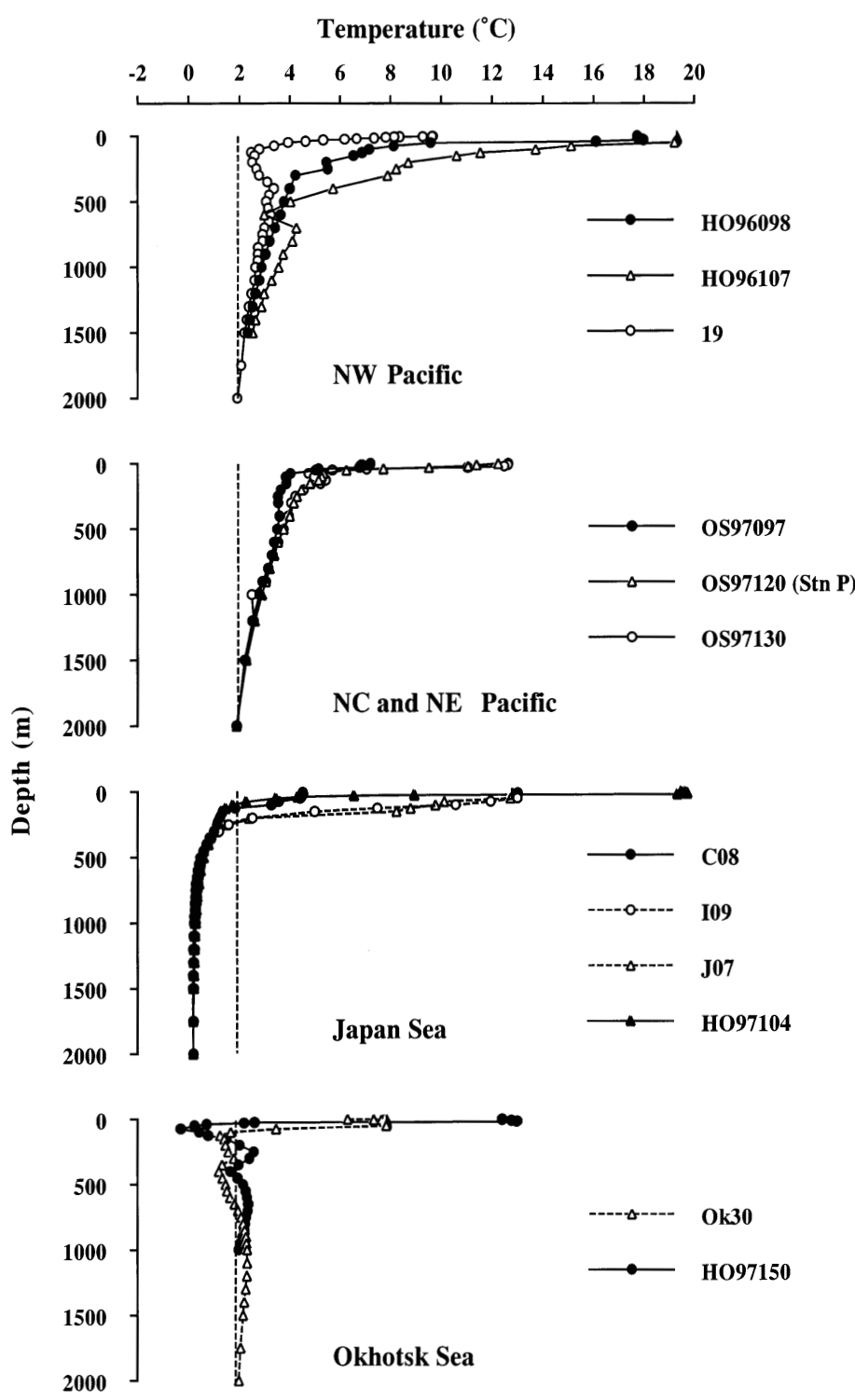

Fig. 3. Vertical structure of temperature $\left({ }^{\circ} \mathrm{C}\right)$ at additional stations in Northwest (NW), Northcentral (NC) and Northeast (NE) subarctic Pacific, and in Japan and Okhotsk Seas. Vertical dashed lines $\left(2^{\circ} \mathrm{C}\right)$ are superimposed to facilitate comparison
Other areas

At 3 stations in the western subarctic Pacific, temperatures in the top $500 \mathrm{~m}$ increased in the order of Stns 19, HO96098, and HO96107 (Fig. 3). Compared with Site H, the upper 500 m of Stns 19 and HO96107 were colder and warmer, respectively, and HO96098 was similar to Site H (except for higher temperatures near the surface layer). The colder temperatures at Stn 19 reflect the influence of cold Okhotsk Sea water; the warmer temperatures at HO96107 are due to the influence of the warm Kuroshio water (cf. Kono 1997, Kono \& Kawasaki 1997). Temperature profiles at Stn OS97097 in the central subarctic Pacific, and Stns OS97120 (Stn P) and OS97130 in the eastern subarctic Pacific were nearly comparable to that at Site $\mathrm{H}$, except that the top $500 \mathrm{~m}$ was slightly warmer in the latter 2 stations. Comparison of annual temperature variation in the top $500 \mathrm{~m}$ at Site H (Fig. 2) and at Stn P (Miller et al. 1984) showed that Site $H$ was characterized by a wider temperature range in the surface layer (2 to 18 and 6 to $14^{\circ} \mathrm{C}$ for site $\mathrm{H}$ and $\mathrm{Stn} \mathrm{P}$, respectively) and lower temperatures in the 200 to $500 \mathrm{~m}$ stratum (2 to 3 and 4 to $5^{\circ} \mathrm{C}$ for site $\mathrm{H}$ and $\mathrm{Stn} \mathrm{P}$, respectively).

The thermal regimes in the marginal seas (Japan Sea and Okhotsk Sea) differed from those in the subarctic Pacific by the presence of water of near-zero temperature (Zenkevitch 1963). This very cold water is termed 'deep-water' in the Japan Sea (Nishimura 1969), and 'cold intermediate water' in the Okhotsk Sea (Kitani \& Shimazaki 1972). At all 4 stations in the Japan Sea, the deep-water was below $500 \mathrm{~m}$. At Stns I09 and J07 in the southern Japan Sea, water temperature in the top $300 \mathrm{~m}$ was higher than at Stns C08 and HO97104 in the northern Japan Sea, perhaps due to the effect of the Tsushima Warm Current (a branch of Kuroshio carrying warm water from the south, Nishimura 1969). Nishimura classified Japan Sea regions as 'subtropical', 'subarctic' and 'arctic' based on biological features. According to his classification, Stns C08 and HO97103/HO97104 in the northern Japan Sea are in the subarctic region, and Stns I09 and J07 in the southern Japan Sea are in the subtropical region. At 2 stations in the Okhotsk Sea, the 'cold intermediate water' was at 30 to $200 \mathrm{~m}$ depth, i.e. shallower than in the Japan Sea. This was especially evident at the southern Stn HO97150.

\section{Population structure}

Site H

Two prominent abundance peaks of the C1 of $\mathrm{Neo}$ calanus plumchrus/flemingeri were observed in March and June 1997 (Fig. 4). By tracing the abundance peaks 
of N. flemingeri for C2 in March, C3 and C4 in April, C5 and C6 males in June, and C6 females in July, it is evident that the earlier peak of the $\mathrm{C} 1$ (March) consists of $N$. flemingeri. Abundance peaks of C1 to C6 all occurred within the high chl a period. Taking into account the sampling gap in this study (ca $1 \mathrm{mo}$ ), the development time from $\mathrm{C} 1$ to $\mathrm{C} 6$ is roughly estimated as 3 to 4 mo. C4 occurred throughout the year although abundance was low in September to December 1996 and May to October 1997. Although C6 males were observed only in May to July 1997, C6 females occurred throughout the year and were abundant in August to December 1996 and July to October 1997.

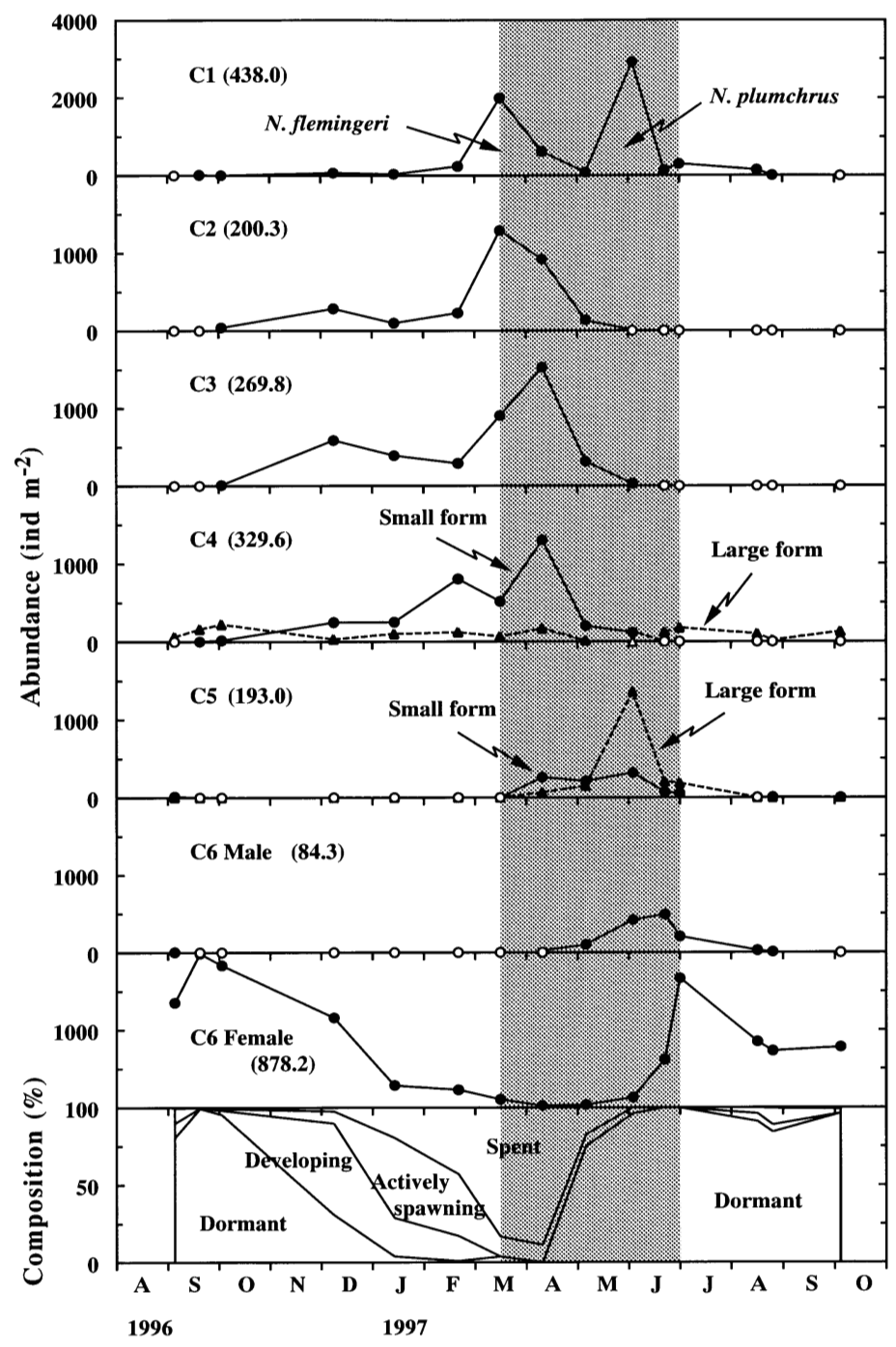

Fig. 4. Neocalanus flemingeri. Seasonal changes in standing stock of each development stage ( $\mathrm{C} 1$ to $\mathrm{C} 6$ ) and composition of dormant, developing, spawning and spent specimens of $\mathrm{C} 6 \mathrm{fe}-$ males at 0 to $2000 \mathrm{~m}$ at Site $\mathrm{H}$ from September 1996 to October 1997. Annual means are shown in parentheses. Shaded area: period of high chlorophyll; $(\bullet)$ occurrence; (O) no occurrence
The reproductive state of the $\mathrm{C} 6$ females varied as a function of sampling date. A large fraction of dormant specimens was observed in September to October 1996 and May to October 1997. In 1996, they were successively replaced by developing specimens in the following 2 to 3 mo. Actively spawning females were abundant from January to February 1997. Spent females were numerous in March to April 1997. Based on all these seasonal features of the population structure and maturity conditions of the females, the life cycle of most Neocalanus flemingeri at Site $\mathrm{H}$ is annual. However, a possible overwintering of a small fraction of the population as $\mathrm{C} 4$ copepodites molting to $\mathrm{C} 5$ in their second year cannot be ruled out.

\section{Other areas}

Compared with the results at Site $\mathrm{H}$, population sizes (expressed as total ind. $\mathrm{m}^{-2}$ of $\mathrm{C} 2$ to $\mathrm{C} 6$ ) were significantly less in the eastern subarctic Pacific (OS97120 and OS97130), the Japan Sea (C08, I09 and J07), and the Okhotsk Sea (Ok30 and HO97150) (Table 2). On the other hand, C2 to C6 population size at the northern stations in the western (Stn 19) and central subarctic Pacific (OS97097) was much greater than that recorded at Site $\mathrm{H}$.

In terms of developmental stage composition, both C4 and C6 females co-occurred in deep samples from the western subarctic Pacific, Japan Sea and Okhotsk Sea. Because the sampling season was autumn/winter, $\mathrm{C} 4$ in these regions were considered to be overwintering populations, as at Site H. However, the most abundant stage at all sites was C6, and C4 was not found in the central and eastern subarctic Pacific, despite similar sampling season.

\section{Vertical distribution}

Site H

C2 to C3 occurred mainly in the top $250 \mathrm{~m}$ from October 1996 to June 1997 (Fig. 5). A large part of the $\mathrm{C} 4$ population was found in the surface layer during the period of high chlorophyll (February to June 1997), and in the thermocline down to $500 \mathrm{~m}$ during the rest of the year. C5, which was absent from September 1996 to March 1997, occurred in the surface layer in April 1997, and sank gradually to $1000 \mathrm{~m}$ depth toward October 1997. All C6 males resided in the 250 to $1000 \mathrm{~m}$ depth layer. C6 females occurred at 500 to $2000 \mathrm{~m}$ in September to October 1996 and August to October 1997, during which time they were dormant; they then migrated upward and were distributed between 250 and $1000 \mathrm{~m}$ in March to July 1997. 
Other areas

C2 to C3 were found mainly in the top $250 \mathrm{~m}$ at Stn 19 in the Japan Sea and Stn Ok30 in the Okhotsk Sea (Fig. 6). A large part of the $\mathrm{C} 4$ population was observed in the thermocline to $1000 \mathrm{~m}$ layer, as during summer/winter at Site $\mathrm{H}$. C5 were abundant in the surface layer only in the central subarctic Pacific, and were in the thermocline to $500 \mathrm{~m}$ stratum at other stations: Stn 19 in the western subarctic Pacific, I09 and J07 in the Japan Sea, and HO97150 in the Okhotsk Sea. C6 males and females occurred abundantly in the 250 to $2000 \mathrm{~m}$ layer at all stations in the entire subarctic Pacific, Japan Sea and Okhotsk Sea. Stage-specific vertical distribution patterns were almost identical to those already described for Site $\mathrm{H}$.
Table 2. Neocalanus flemingeri. Standing stock (ind. $\mathrm{m}^{-2}$ at 0 to $2000 \mathrm{~m}$ depth) and stage composition (\%) of each development stage (C2 to C6) in the subarctic North Pacific and its neighboring waters. Standing stock and stage composition at Site $\mathrm{H}$ are annual means $\left( \pm 95 \%\right.$ CI for the former in parentheses). ${ }^{*} 0$ to $1000 \mathrm{~m}$ depth

\begin{tabular}{|lcrrrrr|}
\hline \multirow{2}{*}{$\begin{array}{l}\text { Area } \\
\text { Station }\end{array}$} & Standing stock & \multicolumn{5}{c|}{ Composition (\%) } \\
& & C2-C3 & C4 & C5 & C6 male C6 female \\
NW Pacific & & & & & & \\
Site H & $1862.5( \pm 510.1)$ & 19.2 & 16.1 & 9.3 & 5.4 & 50.0 \\
HO96098 & 647.9 & 0.0 & 14.4 & 0.0 & 0.0 & 85.6 \\
HO96107 & 418.3 & 0.0 & 10.1 & 0.0 & 1.0 & 88.9 \\
19 & 3717.9 & 58.7 & 10.1 & 0.1 & 0.0 & 31.1 \\
NC Pacific & & & & & & \\
OS97097 & 4950.2 & 0.0 & 0.0 & 89.9 & 10.1 & 0.0 \\
NE Pacific & & & & & & \\
OS97120 (= Stn P) & 786.6 & 0.0 & 0.0 & 0.0 & 7.8 & 92.2 \\
OS97130 & 584.2 & 0.0 & 0.0 & 0.0 & 4.2 & 95.8 \\
Japan Sea & & & & & & \\
C08 & 661.7 & 0.0 & 86.7 & 0.0 & 0.0 & 13.3 \\
I09 & $201.7 *$ & 0.0 & 93.3 & 3.3 & 0.0 & 3.3 \\
J07 & 599.7 & 0.0 & 92.4 & 2.1 & 0.0 & 5.5 \\
HO97103 & 1081.9 & 2.1 & 73.0 & 0.0 & 0.0 & 24.9 \\
HO97104 & 1476.2 & 0.3 & 90.9 & 0.0 & 0.0 & 8.8 \\
Okhotsk Sea & & & & & & \\
Ok30 & 850.5 & 28.1 & 40.2 & 0.0 & 0.0 & 31.6 \\
HO97150 & 1252.2 & 0.0 & 36.4 & 1.1 & 4.0 & 58.4 \\
\hline
\end{tabular}

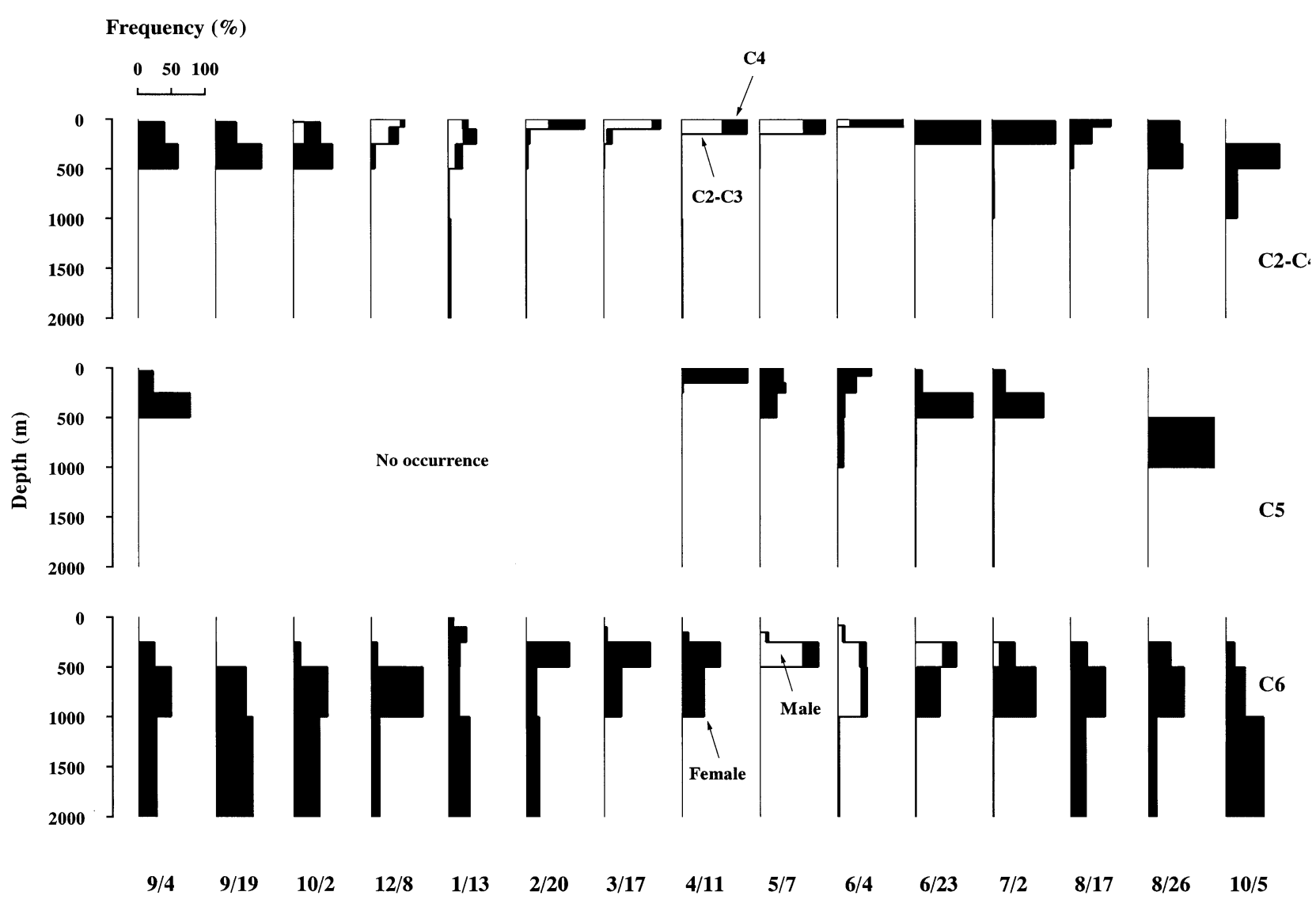

Fig. 5. Neocalanus flemingeri. Seasonal changes in vertical distribution of C2 to C4, C5 and C6 at Site H from September 1996 to October 1997. Date (mo/d) of sampling is shown on bottom abscissa 


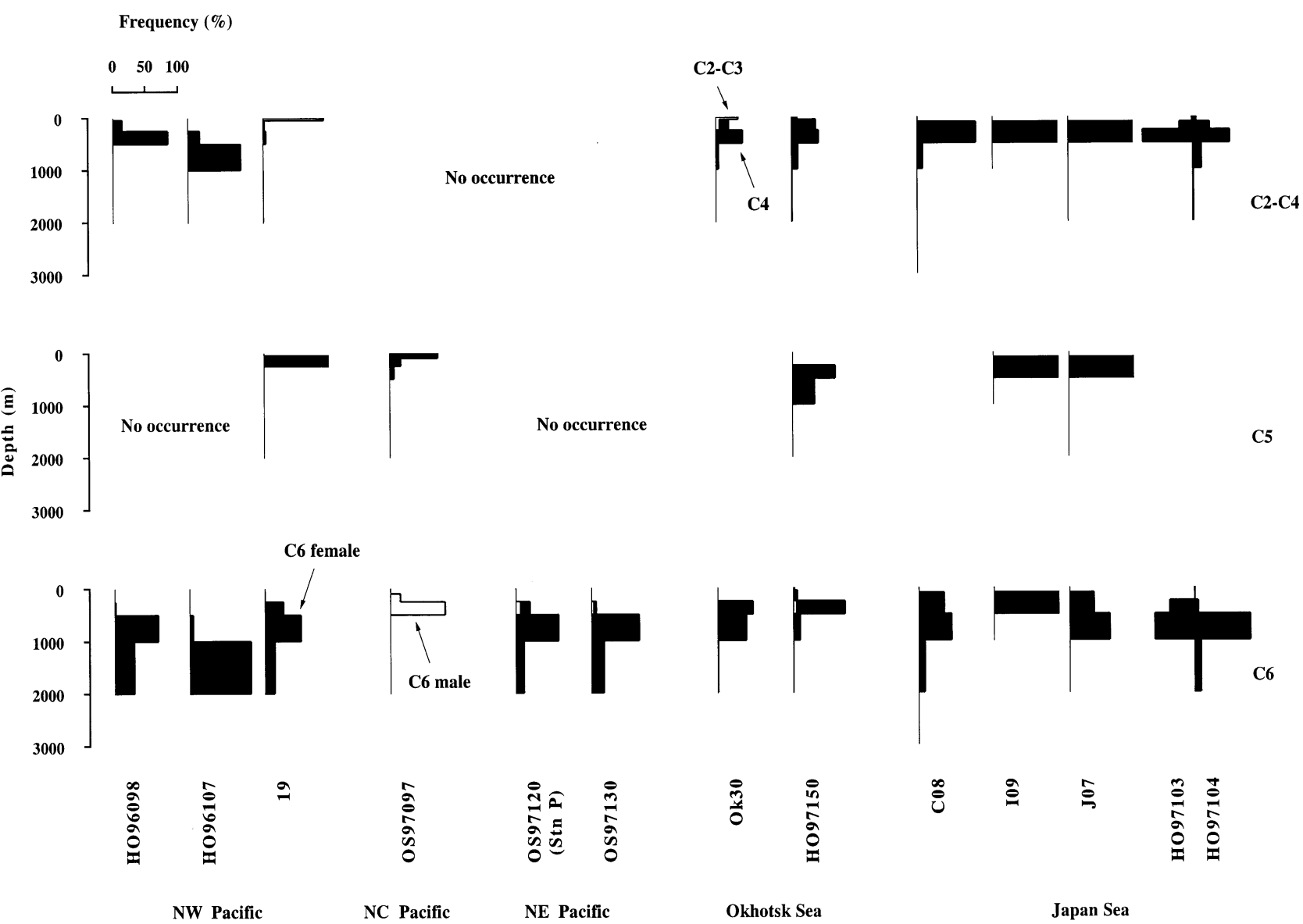

Fig. 6. Neocalanus flemingeri. Regional variations in vertical distribution of C2 to C4, C5 and C6 at additional stations in Northwest (NW), Northcentral (NC) and Northeast (NE) Pacific, and in Japan and Okhotsk Seas

\section{Prosome length}

Site H

Prosome length increased steadily with development from $\mathrm{C} 1$ to $\mathrm{C} 6$. However, the size distributions of prosome length were unimodal in $\mathrm{C} 2, \mathrm{C} 3, \mathrm{C} 6$ males and C6 females, but bimodal in C4 and C5 (Fig. 7). Large $\mathrm{C} 4$ was less abundant than small $\mathrm{C} 4$, but they nevertheless constituted nearly the entire overwintering $\mathrm{C} 4$ population (Fig. 4). On the other hand, large C5 were more numerous than small C5, and both occurred during the period of high chlorophyll (Fig. 4). The largeform:small-form ratio of the prosome length was 1.25:1 for $\mathrm{C} 4$, and 1.20:1 for C5.

\section{Other areas}

While the prosome lengths of C5, C6 males and C6 females were determined, only female C6 data were used for regional comparison, because few data were available for C5 and C6 males (Table 3). The prosome length of C6 females was greatest in the Okhotsk Sea and smallest in the eastern and part of the western (HO96098) subarctic Pacific, with intermediate lengths in the western subarctic Pacific including Site $H$, and the Japan and Bering Seas (1-way ANOVA and Scheffé's F).

\section{DISCUSSION}

\section{Life cycle}

According to Miller \& Clemons (1988), spawning of Neocalanus flemingeri at Stn P in the Gulf of Alaska occurs in January, and resultant offspring develop in the surface layer from February through May until they reach the pre-adult C5 stage. C5 individuals then descend from the surface layer in May/June and molt immediately to adults (C6). C6 males live for about 2 mo, and C6 females with attached spermatophores are found during June/July. Throughout the remainder of summer and autumn, the entire population is constituted of C6 females with small, immature ovaries (perhaps a diapause phase). Ovarian development be- 


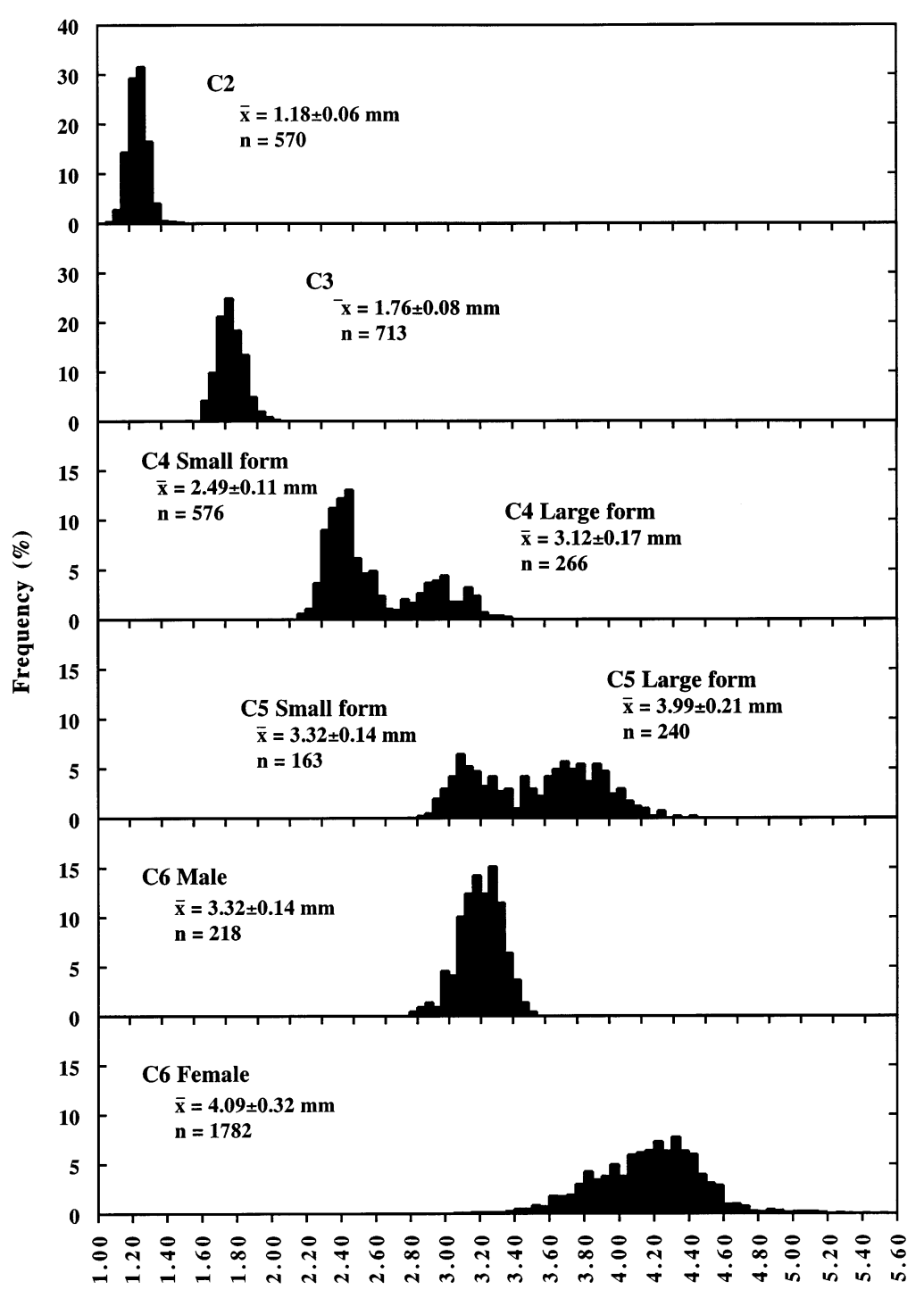

Prosome length (mm)

Fig. 7. Neocalanus flemingeri. Frequency-distribution of prosome length of each copepodite stage (C2 to C6) at Site H from September 1996 to October 1997. $\bar{x}$ : annual mean, n: number of specimens measured

The life-cycle pattern of the main population of Neocalanus flemingeri at Site $\mathrm{H}$ in the Oyashio region is very similar to that at Stn $\mathrm{P}$ in terms of its ontogenetic vertical migration pattern, spawning timing, shortlived C6 males, and long-lived dormant C6 females (cf. Figs. 4 \& 5). The only difference between our results and those of Miller \& Clemons (1988) is the occurrence of a small overwintering population of $\mathrm{C} 4$ at Site $\mathrm{H}$. Adopting the interpretation of Miller \& Terazaki (1989) for the $N$. flemingeri population in the Japan Sea, this small C4 population overwintering at Site $\mathrm{H}$ may require 2 yr to complete its life cycle (Fig. 8).

Assuming that overwintering $\mathrm{C} 4$ and $\mathrm{C} 6$ females represent biennial and annual life cycles of Neocalanus flemingeri, respectively, the population structure data of other areas (Table 2) provide some insight into large-scale regional variations in the relative importance of the 2 life cycles of this copepod. Our observation of overwintering C4 in the Japan Sea but only C6 females in the eastern subarctic Pacific confirms the previous results of Miller \& Terazaki (1989) and Miller \& Clemons (1988), respectively. While overwintering $\mathrm{C} 4$ were not seen in the central subarctic Pacific, C4 were collected in the Okhotsk Sea and, to a small extent, in the western subarctic Pacific, including Site H. These results suggest that, for the subarctic Pacific and its marginal seas, a biennial life cycle is characteristic for a significant fraction of individuals from western Pacific populations. A biennial life cycle is not found among individuals from central and eastern Pacific populations. The differences in the life-cycle modes of $N$. flemingeri may be a response to east-west dissimilarities (see later subsection 'Regional body size variation'); i.e. overwintering

gins in November and spawning occurs in January. Thus, the life cycle of $N$. flemingeri is annual at Stn P.

The life cycle of Neocalanus flemingeri in the Japan Sea is somewhat different from that at Stn $\mathrm{P}$ because there appears to be 2 alternative diapause stages: C4 and C6 females. The latter type is the same as that observed in Stn P population (Miller \& Clemons 1988). Miller \& Terazaki (1989) hypothesized that the population diapausing as $\mathrm{C} 4$ during summer/winter might develop to $\mathrm{C} 5$, and then to $\mathrm{C} 6$ in the following year (i.e. biennial life cycle). Thus, there may be $2 \mathrm{~N}$. flemingeri populations in the Japan Sea distinguished by annual versus biennial life cycles.
C4 (biennial individuals) in the western region may represent those individuals that failed to encounter sufficient food and/or slower development in cooler conditions.

\section{Sexual dimorphism}

Among the C2 to C6 stages of Neocalanus flemingeri, the size distributions of $\mathrm{C} 4$ and $\mathrm{C} 5$ exhibited 2 modes, while all other stages showed only 1 mode (Fig. 7). Tsuda et al. (1999) interpreted the bimodal size distribution of C4 and C5 as a mixture of 2 populations with 
Table 3. Neocalanus flemingeri. Prosome length (PL: mm) of C5 and C6 (males and females) in the subarctic North Pacific and its neighboring waters. Regional comparison was made for C6 females only against the means at Site H, OS97120 (the smallest mean) and HO97150 (the largest mean) (1-way ANOVA, Scheffé's $F$ ). Number of specimens in parenthesis.,$+-:$ significantly greater or smaller, respectively, at $\mathrm{p}<0.05(+,-), \mathrm{p}<0.01(++,--)$ and $\mathrm{p}<0.001(+++,---)$. nd: no data

\begin{tabular}{|c|c|c|c|c|c|c|c|c|c|}
\hline \multirow{3}{*}{$\begin{array}{l}\text { Area } \\
\text { Station }\end{array}$} & \multicolumn{6}{|c|}{ Prosome length } & \multirow{2}{*}{\multicolumn{3}{|c|}{$\begin{array}{l}\text { C6 female } \\
\text { Compared with }\end{array}$}} \\
\hline & \multirow{2}{*}{$\begin{array}{l}\text { Mean } \pm \text { SD } \\
\text { Mear }\end{array}$} & \multirow[t]{2}{*}{$\overline{(\mathrm{n})}$} & \multirow[t]{2}{*}{$\begin{array}{l}\text { Mean } \pm \mathrm{SD}\end{array}$} & \multirow{2}{*}{ (n) } & \multirow{2}{*}{ Mean \pm SD } & \multirow{2}{*}{ (n) } & & & \\
\hline & & & & & & & Site H & OS97120 & HO97150 \\
\hline \multicolumn{10}{|l|}{ NW Pacific } \\
\hline Site H & $3.67 \pm 0.38$ & $(403)$ & $3.32 \pm 0.14$ & $(218)$ & $4.09 \pm 0.32$ & $(1782)$ & & +++ & --- \\
\hline 19 & 3,75 & $(1)$ & nd & & $4.08 \pm 0.30$ & $(211)$ & & +++ & --- \\
\hline HO96098 & nd & & nd & & $3.61 \pm 0.27$ & $(100)$ & --- & & --- \\
\hline HO96107 & nd & & nd & & $3.81 \pm 0.36$ & $(21)$ & & & --- \\
\hline \multicolumn{10}{|l|}{ NC Pacific } \\
\hline OS97097 & $3.36 \pm 0.14$ & $(244)$ & $3.06 \pm 0.10$ & (85) & nd & & & & \\
\hline \multicolumn{10}{|l|}{ NE Pacific } \\
\hline OS97130 & nd & & $2.92 \pm 0.98$ & (6) & $3.50 \pm 0.14$ & (72) & --- & & --- \\
\hline OS97120 (= Stn P) & nd & & $3.02 \pm 0.63$ & (10) & $3.63 \pm 0.13$ & $(102)$ & --- & & --- \\
\hline \multicolumn{10}{|l|}{ Bering Sea } \\
\hline W303 & nd & & nd & & $3.96 \pm 0.23$ & $(26)$ & & & --- \\
\hline \multicolumn{10}{|l|}{ Japan Sea } \\
\hline С08 & nd & & nd & & $4.06 \pm 0.21$ & (16) & & ++ & --- \\
\hline HO97103/HO97104 & nd & & nd & & $4.20 \pm 0.31$ & $(100)$ & & +++ & --- \\
\hline I09 & 3.80 & (1) & nd & & 4.00 & (1) & & & \\
\hline J07 & 3.70 & $(1)$ & nd & & 3.90 & (1) & & & \\
\hline \multicolumn{10}{|l|}{ Okhotsk Sea } \\
\hline Ok30 & nd & & nd & & $4.47 \pm 0.45$ & $(83)$ & +++ & +++ & \\
\hline HO97150 & 3.70 & (2) & $3.24 \pm 0.17$ & (10) & $4.57 \pm 0.42$ & $(154)$ & +++ & +++ & \\
\hline
\end{tabular}

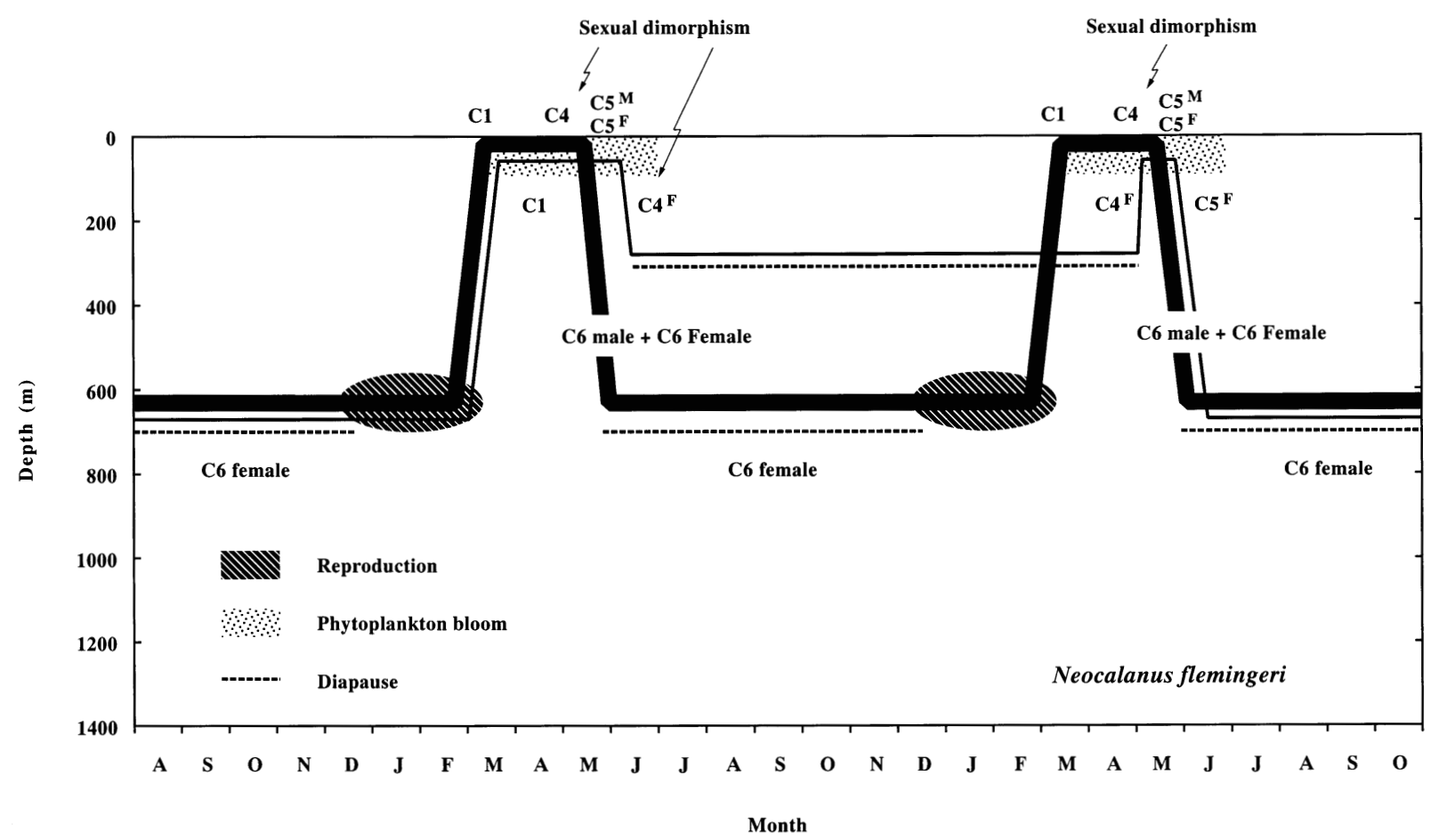

Fig. 8. Neocalanus flemingeri. Life cycle in Oyashio region. Annual life cycle trajectory is shown by thick line and biennial life cycle trajectory by thin line. Superscripts (M: male, F: female) denote expression of sexual dimorphism in C4 and C5 
annual (small size, Oyashio population) and biennial (large size, Okhotsk Sea population) life cycles. Bimodal size modes of C6 females and males are less pronounced in Tsuda et al.'s data. Unfortunately the sampling depth (400 to $900 \mathrm{~m}$ ) employed by Tsuda et al. was apparently not deep enough to collect the entire population of the C6 living >1000 m (cf. Fig. 5 of present study); therefore the size-distribution data of their C6 is subject to possible error. In fact, the size-frequency distributions of C6 females and males were unimodal in the present material collected down to $2000 \mathrm{~m}$ (Fig. 7).

As an alternative explanation for the observed bimodal size distribution of C4 and C5, we suggest sexual dimorphism within the same population. We hypothesize that the small-form $\mathrm{C} 4$ are sex-undetermined, and the small C5 are males, and the large form C4 and C5 are all females. To support this, the mean prosome length ratios of large to small specimens are 1.25:1 for C4, and 1.20:1 for C5, both of which are close to the prosome length ratio of females to males $(1.23: 1)$ of $\mathrm{C} 6$ adults. The mouth parts of adult Neocalanus flemingeri are reduced and nonfunctional (Miller 1988), implying that little dimensional change from pre-adult (C5) prosome length ratios would occur in adults. Comparing the 2 different size groups with the annual and biennial life cycles of $N$. flemingeri discussed above, 2 development scenarios of late-copepodite stages are considered possible, i.e. biennial life cycle: C3, large overwintering $\mathrm{C} 4$ females, large C5 females, C6 females; and an annual life cycle: C3, small C4 (sex-undeveloped), small male and large female C5, and male and female C6 (Fig. 8). In crustaceans, environmental factors such as feeding conditions, population density, temperatures, etc. are known to induce female characters (cf. Ginsburgur-Vogel \& Charniaux-Cotton 1982), but mechanisms controlling the developoment of the C3 to large (female) or small (sex-undeveloped) C4 are presently unknown. In addition to Site $\mathrm{H}$, we observed a bimodal size distribution of $\mathrm{C} 5$ in the central subarctic Pacific (small form: $\bar{x}=3.15 \pm 0.09 \mathrm{~mm}, \mathrm{n}=298$; large form: $\bar{x}=3.45 \pm 0.08 \mathrm{~mm}, \mathrm{n}=172$ ), but the number of the $\mathrm{C} 4$ and $\mathrm{C} 5$ specimens was too few at other stations to analyze (Table 2).

Bimodal body-length distributions have been reported for the C4 and C5 stages of Calanus finmarchicus and C. helgolandicus (Ussing 1938, Barnes \& Barnes 1953, Marshall \& Orr 1955, Woodhead \& Riley 1957, 1959, Grigg et al. 1981, 1985, 1987), and explained for these species by sexual dimorphism (Woodhead \& Riley 1957, 1959, Tande \& Hopkins 1981, Grigg et al. 1987). According to Woodhead \& Riley (1957, 1959), sexual size dimorphism in C5 of C. finmarchicus and $C$. helgolandicus appears not only as total body size but also as morphology of the first urosome segment. However, we could not find any morphological differences between small and large size groups of C4 and C5 of Neocalanus flemingeri in the present study. According to Tande \& Hopkins (1981) and Kosobokova (1998), the number of genital ducts is useful for separating males (single) from females (2) at C5 of C. finmarchicus and C. glacialis, but we did not examine this for $N$. flemingeri in this study.

\section{Regional body-size variation}

Body size of marine copepods is known to be influenced by water temperature and food availability, both in laboratory experiments (e.g. Corkett \& McLaren 1978, Escribano \& McLaren 1992) and from field-data analysis (e.g. Digby 1954, Deevey 1960). In general, lower temperature and higher food concentration produce larger body size in copepods. In the following discussion, we assumed that Neocalanus flemingeri is primarily a grazer, and used chl a concentration as an index of phytoplankton abundance.

Between-habitat comparisons of prosome length revealed that Neocalanus flemingeri from the Okhotsk Sea have the longest prosomes while those from the eastern (OS97120 and OS97130) and part of the western (HO96098) oceanic subarctic Pacific have the shortest (Table 3). Together with high chl a concentrations (max. $5 \mathrm{mg} \mathrm{m}^{-3}$, Saitoh et al. 1996), the large body size of $N$. flemingeri in the Okhotsk Sea may be explained by the positive effect of lower habitat temperature due to the cold intermediate water, characterized by subzero temperature (Kitani \& Shimazaki 1972 and present Fig. 3). In contrast, a warmer habitat temperature (Fig. 3) or the combined effects of a warm habitat temperature and low chl a $\left(6\right.$ to $13^{\circ} \mathrm{C}$, Miller et

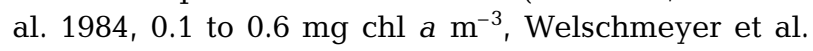
1993) may explain the small body size of $N$. flemingeri in the oceanic gyre regions. In the Japan Sea, moderate chl a concentrations (max. 2 to $3 \mathrm{mg} \mathrm{m}^{-3}$; $\mathrm{S}$. Kim et al. pers. comm.) and low deep-water temperatures $\left(<1^{\circ} \mathrm{C}_{\text {; Fig. }}\right.$ ) $)$ are similar to those in the Okhotsk Sea, but the size of $N$. flemingeri in the Japan Sea is less than in the Okhotsk Sea, suggesting possible modification of the Japan Sea waters by the overlying Tsushima Warm Current. The intermediate body size of N. flemingeri in the western subarctic Pacific, including Site $\mathrm{H}$ and the Bering Sea, suggests that the combined effects of temperature and food phytoplankton conditions are similar in these 2 regions. In his original description of N. flemingeri, Miller (1988) noted regional variations in the size (C6 female), including specimens collected from Stn P, western subarctic Pacific, Japan Sea and Bering Sea. While Miller gave no interpretation for these regional variations, our data are in good agreement with his results (Table 3 ) for the same regions. 
Three sympatric Neocalanus species occur at Site $\mathrm{H}$ in the Oyashio region. In addition to the present study on $N$. flemingeri, the life-cycle patterns of $N$. cristatus and $N$. plumchrus have also been evaluated (Kobari \& Ikeda 1999a,b). These 3 species are similar in that they display large-scale ontogenetic migration (600 to $1000 \mathrm{~m}$ ), spawn at depths below $250 \mathrm{~m}$, and achieve rapid growth during their residence in the surface layer. However, in the Oyashio region there are some between-species differences in the timing of active development in the surface layer (order: $N$. cristatus $>$ $N$. flemingeri $>N$. plumchrus), and the depth stratum during diapause $(N$. cristatus $>N$. plumchrus $>N$. flemingeri), thus facilitating niche separation in time and space (cf. Tsuda et al. 1999). Further, Mackas et al. (1993) observed a small-scale vertical partitioning of these 3 copepods during their copepodite growth season, i.e. $N$. cristatus resides below $N$. flemingeri and $N$. plumchrus. In addition, the present results illustrate that the life-cycle patterns of $N$. flemingeri are more complex than those of $N$. cristatus and $N$. plumchrus in that the former possibly displays sexual dimorphism in late-copepodite stages and comprises a mixture of individuals with annual and biennial life cycles.

Acknowledgements. We are grateful to D. L. Mackas for critically reading the manuscript and for valuable comments. We thank A. Tsuda, H. Saito and H. Kasai for providing us with part of the zooplankton samples and the chl a data for Site H. Thanks are extended to the 3 anonymous reviewers; their comments significantly improved the manuscript.

\section{LITERATURE CITED}

Barnes H, Barnes M (1953) Biometry of the copepod Calanus finmarchicus (Gunn.) in stages V and VI. J Mar Biol Assoc UK 32:305-313

Corkett CJ, McLaren IA (1978) The biology of Pseudocalanus. Adv Mar Biol 15:1-231

Deevey GB (1960) Relative effects of temperature and food on seasonal variations in length of marine copepods in some eastern American and western European waters. Bull Bingham Oceanogr Coll 17:54-87

Digby PSB (1954) The biology of the marine planktonic copepods of Scoresby Sound, east Greenland. J Anim Ecol 23: 298-338

Escribano R, McLaren IA (1992) Influence of food and temperature on length and weights of two marine copepods. J Exp Mar Biol Ecol 159:77-88

Favorite F, Dodimead AJ, Nasu K (1976) Oceanography of the subarctic Pacific region, 1960-1971. Bull Int N Pacif Fish Commn 33:1-187

Fukataki H (1967) Stomach contents of the pink salmon, Oncorhynchus gorbuscha (Walmaum), in the Japan Sea during spring season of 1965. Bull Jpn Sea Reg Fish Lab $17: 49-66$

Fukataki H (1969) Stomach contents of the Masu salmon, Oncorhynchus masou (Brevoort), in the offshore regions of the Japan Sea. Bull Jpn Sea Reg Fish Lab 21:17-34
Ginsburgur-Vogel T, Charniaux-Cotton H (1982) Sex determination. In: Bliss DE (ed) The biology of Crustacea. Academic Press, New York, p 257-281

Grigg H, Bardwell SJ, Tyzack S (1981) Patterns of variation in the prosome length of overwintering stage $\mathrm{V}$ copepodites of Calanus finmarchicus in the Firth of Clyde. J Mar Biol Assoc UK 61:885-899

Grigg H, Holmes LJ, Bradwell SJ (1985) Seasonal observations on the biometry and development in Copepodite Stage V of Calanus finmarchicus from the Firth of Clyde. Mar Biol 88:73-83

Grigg H, Bardwell SJ, Holmes LJ (1987) Comparative observations on the biometry and development of Calanus finmarchicus and C. helgolandicus in copepodite stage V, with comments on other Calanidae. Mar Biol 96:253-262

Hunt GL, Russell RW, Coyle KO, Weingartner T (1998) Comparative foraging ecology of planktivorous auklets in relation to ocean physics and prey availability. Mar Ecol Prog Ser 167:241-259

Kawamura A (1968) Performance of Petersen type vertical closing net. Bull Plankton Soc Jpn 15:11-12

Kawamura A (1989) Fast sinking mouth ring for closing NORPAC net. Bull Jpn Soc Sci Fish 55:1121

Kitani K, Shimazaki K (1972) On the hydrography of the northern part of the Okhotsk Sea in summer. Bull Fac Fish Hokkaido Univ 22:231-242

Kobari T, Ikeda T (1999a) Life cycle of Neocalanus plumchrus (Crustacea: Copepoda) in the Oyashio region (extended Abstract). In: Terazaki M, Ohtani K, Sugimoto T, Watanabe Y (eds) Ecosystem dynamics of the Kuroshio-Oyshio Transition Region. Japan Marine Science Foundation, Tokyo, p 141-144

Kobari T, Ikeda T (1999b) Vertical distribution, population structure and life cycle of Neocalanus cristatus (Crustacea: Copepoda) in the Oyashio region, with notes on its regional variations. Mar Biol 134:683-696

Kono T (1996) Modification processes of the intermediate subarctic water in the western North Pacific and its relation to formation of the North Pacific intermediate water. Bull Hokkaido Natl Fish Res Inst 60:145-223

Kono T (1997) Modification of the Oyashio Water in the Hokkaido and Tohoku areas. Deep-Sea Res 44:669-688

Kono T, Kawasaki Y (1997) Modification of the western subarctic water by exchange with the Okhotsk Sea. Deep-Sea Res 44:689-711

Kosobokova KN (1998) New data on the life cycle of Calanus glacialis in the White Sea (based on seasonal observations of its genital system development). Oceanology 38:47-355

Mackas DL, Sefton H, Miller CB, Raich A (1993) Vertical habitat partitioning by large calanoid copepods in the oceanic subarctic Pacific during spring. Prog Oceanogr 32: $259-294$

Marshall SM, Orr AP (1955) The biology of a marine copepod Calanus finmarchicus (Gunnerus). Oliver \& Boyd, London

Miller CB (1988) Neocalanus flemingeri, a new species of Calanidae (Copepoda: Calanoida) from the subarctic Pacific Ocean, with a comparative redescription of Neocalanus plumchrus (Marukawa) 1921. Prog Oceanogr 20:223-273

Miller CB, Clemons MJ (1988) Revised life history analysis for large grazing copepods in the subarctic Pacific Ocean. Prog Oceanogr 20:293-313

Miller CB, Terazaki M (1989) The life histories of Neocalanus flemingeri and Neocalanus plumchrus in the Sea of Japan. Bull Plankton Soc Jpn 36:27-41

Miller CB, Frost BW, Batchelder HP, Clemons MJ, Conway RE (1984) Life histories of large, grazing copepods in a subarctic ocean gyre: Neocalanus plumchrus, Neocalanus 
cristatus, and Eucalanus bungii in the Northeast Pacific. Prog Oceanogr 13:201-243

Nemoto T (1963) Some aspects of the distribution of Calanus cristatus and C. plumchrus in the Bering Sea and its neighbouring waters, with reference to the feeding of baleen whales. Sci Rep Whales Res Inst, Tokyo 17:157-170

Nishimura S (1969) The zoogeographical aspects of the Japan Sea: Part V. Publs Seto Mar Biol Lab 17:67-142

Odate K (1994) Zooplankton biomass and its long-term variation in the western North Pacific Ocean, Tohoku Sea area, Japan. Bull Tohoku Natl Fish Res Inst 56:115-173

Ohtani K (1971) Studies on the change of the hydrographic conditions in the Funka Bay. II. Characteristics of the waters occupying the Funka Bay. Bull Fac Fish Hokkaido Univ 22:58-66

Reid JL (1973) North Pacific Ocean waters in winter. The Johns Hopkins Press, Baltimore, p 1-96

Saitoh S, Kishino M, Kiyohuji H, Tagichi S, Takahashi M (1996) Seasonal variability of phytoplankton pigment concentration in the Okhotsk Sea. J Remote Sensing Soc Jpn 16:86-92

Taka S, Kitakata M, Wada T (1982) The relations between the saury, Cololabis saira (Brevoort) and the food organisms on, especially Calanus plumchrus, in the southeast waters of Kuril Islands during the summer. Bull Hokkaido Reg Fish Res Lab 47:41-55

Tande KS, Hopkins CCE (1981) Ecological investigations of the zooplankton community of Balsfjorden, northern Norway: the genital system in Calanus finmarchicus and the

Editorial responsibility: Mike Landry (Contributing Editor), Honululu, Hawaii, USA role of gonad development in overwintering strategy. Mar Biol 63:159-194

Tsuda A, Sugisaki H (1994) In situ grazing rate of the copepod population in the western subarctic North Pacific during spring. Mar Biol 120:203-210

Tsuda A, Saito H, Kasai H (1999) Life histories of Neocalanus flemingeri and Neocalanus plumchrus (Calanoida: Copepoda) in the western subarctic Pacific. Mar Biol 135: $533-544$

UNESCO (1968) Zooplankton sampling. Monogr Oceanogr Methodol (UNESCO) 2:1-174

Ussing HH (1938) The biology of some important plankton animals in the Fjords of East Greenland. Meddt Grønland 100:1-100

Vinogradov ME (1970) Vertical distribution of the oceanic zooplankton. Israel Program for Scientific Translations, Jerusalem

Welschmeyer NA, Strom S, Goericke R, Ditullio G, Belvin M, Petersen W (1993) Primary production in the subarctic Pacific Ocean: Project SUPER. Prog Oceanogr 32:101-135

Woodhead PMJ, Riley JD (1957) Separation of potential males and females in stage- $\mathrm{V}$ copepodites of Calanus helgolandicus. J Cons Int Explor Mer 23:47-50

Woodhead PMJ, Riley JD (1959) Separation of the sexes of Calanus finmarchicus (Gunn.) in the fifth copepodite stage, with comments on the sex ratio and the duration in this stage. J Cons Int Explor Mer 24:465-471

Zenkevitch L (1963) Biology of the seas of the U.S.S.R. George Allen \& Unwin, London

Submitted: November 15, 1999; Accepted: June 22, 2000 Proofs received from author(s): November 27, 2000 